\title{
ESSENTIAL OILS OF Myrcia lundiana Kiaersk AND THEIR MAJOR COMPOUNDS SHOW DIFFERENTIATED ACTIVITIES AGAINST THREE PHYTOPATHOGENIC FUNGI
}

\author{
ÓLEOS ESSENCIAIS DE Myrcia lundiana Kiaersk E SEUS COMPOSTOS \\ MAJORITÁRIOS APRESENTAM ATIVIDADES DIFERENCIADAS SOBRE TRÊS \\ FUNGOS FITOPATOGENNICOS
}
Mércia Freitas ALVES ${ }^{1}$; Arie Fitzgerald BLANK ${ }^{2}$; Paulo Roberto GAGLIARDI ${ }^{2}$; Maria de Fátima ARRIGONI-BLANK ${ }^{2}$; Daniela Aparecida de Castro NIZIO ${ }^{1}$; Fabiany de Andrade BRITO ${ }^{3}$; Taís Santos SAMPAIO ${ }^{1}$

1. Doutora em Biotecnologia, Universidade Federal de Sergipe - UFS, São Cristóvão, SE, Brasil. merciafreitas.alvs@ gmail.com; 2. Professor, Doutor, Departamento de Engenharia Agronômica - UFS, São Cristóvão, SE, Brasil; 3. Doutoranda em Agricultura e Biodiversidade, UFS, São Cristovão, SE, Brasil.

\begin{abstract}
The present study evaluated the antifungal activity of the essential oils of chemotypes of Myrcia lundiana and their major compounds on the fungi Fusarium pallidoroseum, Fusarium solani, and Colletotrichum musae. The essential oils were obtained by hydrodistillation and analyzed by GCMS/FID. For the evaluation of the antifungal activity, the essential oils and the major compounds were tested at the concentration of $0.1 \mathrm{~mL} / \mathrm{L}$ until the fungicidal effect was detected. The major compounds detected in the essential oil were 1,8-cineole, isopulegol, and citral. The chemotypes (MLU-005 and MLU-019) provided 100\% mycelial growth inhibition for the fungus $F$. pallidoroseum from the concentration of $1.1 \mathrm{~mL} / \mathrm{L}$ (minimum inhibition concentration - MIC). For chemotype (MLU-022), the minimum fungicidal concentration (MFC) was $0.3 \mathrm{~mL} / \mathrm{L}$. For $F$. solani, the essential oils of the chemotypes (MLU-005 and MLU019) presented MIC at concentrations of 7.0 and $5.0 \mathrm{~mL} / \mathrm{L}$, respectively. The essential oil of the chemotype (MLU-022) presented MFC of $0.6 \mathrm{~mL} / \mathrm{L}$. Different MIC was observed for the three studied chemotypes for the fungus $C$. musae, ranging between $0.4 \mathrm{~mL} / \mathrm{L}$, for the chemotype (MLU-005); $0.5 \mathrm{~mL} / \mathrm{L}$, for the chemotype (MLU-022); and $0.7 \mathrm{~mL} / \mathrm{L}$, for the chemotype (MLU-019). The best MFC was observed for the chemotype (MLU-005) $(0.5 \mathrm{~mL} / \mathrm{L})$. The major compounds tested separately presented better MIC values when compared with their chemotypes, except for the compound 1,8-cineole, which presented lower mycelial growth inhibition for the three fungi tested, suggesting that the chemical profile or the presence of some other compound of the essential oil may inhibit the growth of the three fungi studied. The compound isopulegol provided lower MFC for the fungus $C$. musae $(0.4517 \mathrm{~mL} / \mathrm{L})$ when compared with the fungi $F$. pallidoroseum and $F$. solani, (MFC of $0.4927 \mathrm{~mL} / \mathrm{L}$ ). The compound citral provided a lower MFC on the fungus $C$. musae $(0.1668 \mathrm{~mL} / \mathrm{L})$ in relation to the other fungi tested. The essential oils of the chemotypes of M. lundiana and their major compounds showed potential to control the studied phytopathogens and can be an alternative for agriculture for presenting an inhibitory and fungicidal effect against these organisms at lower concentrations.
\end{abstract}

KEYWORDS: Myrtaceae. Volatile oil. Monoterpenes. Lasiodiplodia theobromae. Fusarium pallidoroseum. Fusarium solani.

\section{INTRODUCTION}

Population growth has reduced the areas intended to agricultural cultivation and increased the demand for food. Predictions on the population growth reveal that in the year of 2050 the world population will reach 9 billion inhabitants (CARRER et al., 2010), and thus, food production will become a challenge. Faced with all the factors that reduce food production, fungal diseases have a great impact on agriculture for being destructive and affecting the whole production.

The fungi Fusarium pallidoroseum, Fusarium solani, and Colletotrichum musae stand out among the phytopathogens of interest in agriculture. The species $F$. pallidoroseum is a saprophyte, causing plant deterioration, post-harvest root and fruit rot, or leaf deterioration in several plants; moreover, it can make part of a disease complex when present together with other fungi and phytonematodes (TERAO et al., 2009). The fungus $F$. solani attacks several crops, such as potato, cassava, and yam (tuber rot); pea (stem rot); soybean (sudden death syndrome); and beans (dry root rot) (CRUZ et al., 2015; SAMEZA et al., 2016).

C. musae, in its turn, causes anthracnose in banana, which impairs commercialization and in natura consumption, and can cause losses of up to $40 \%$ of the production (PESSOA et al., 2007; ROZWALKA et al., 2010). 
These fungi have been controlled with the massive use of fungicides, sometimes without registration for the crop, due to the lack of products registered for a given crop. These actions lead to the chemical contamination of the products, which are subject to rejection by the importer. In addition, they cause the emergence of resistant races. Therefore, the reduction or elimination of agrochemicals in disease control has become an economic imperative and no longer an option (TERAO et al., 2009).

To maintain crop sustainability and economic viability, strategies of alternative control must be developed by integrating a clean technology that seeks to reduce or even eliminate the risks of chemical contamination. The focus is to guarantee product quality and preserve population's health, consequently ensuring the competitiveness of the agricultural product (TERAO et al., 2009).

Myrcia lundiana presents excellent antifungal potential. The species belongs to the family Myrtaceae, and is a shrub that produces essential oils with high levels of 1,8-cineole, isopulegol, neral, geranial, and nerolic acid (ALVES et al., 2016). The antifungal activity of its essential oil has already been proved against Lasiodiplodia theobroma. However, only a few studies have reported the effects of the essential oil of this plant on other phytopathogenic fungi that attack crops. This work aimed to evaluate the activity of the chemotypes of the essential of $M$. lundiana and their major compounds 1,8-cineole, citral, and isopulegol against the phytopathogenic fungi $F$. pallidoroseum, F. solani, and C. musae .

\section{MATERIAL AND METHODS}

\section{Plant material and essential oil extraction}

The essential oils of the chemotypes MLU005, MLU-019, and MLU-022 were characterized by Alves et al. 2016. Leaves were collected in the municipality of Areia Branca, in the state of Sergipe, northeast of Brazil. The plants were manually defoliated and dried in a forced-aircirculation oven at $40{ }^{\circ} \mathrm{C}$ for five days. The essential oil was extracted by hydrodistillation in a modified Clevenger apparatus, using $50 \mathrm{~g}$ of dry leaf for 140 minutes (EHLERT et al., 2006). Essential oils were collected and stored in amber flasks at $-20{ }^{\circ} \mathrm{C}$ until chemical composition analysis. The compounds 1,8cineole, isopulegol, and citral were purchased from the corporation Sigma-Aldrich.

\section{Chromatographic analyses}

The analysis of the chemical composition of the essential oils was carried out using a GC-
MS/FID (QP2010 Ultra, Shimadzu Corporation, Kyoto, Japan), equipped with an autosampler AOC$20 \mathrm{i}$ (Shimadzu). Separations were accomplished using an Rtx ${ }^{\circledR}-5$ MSRestek fused silica capillary column (5\%-diphenyl-95\%-dimethylpolysiloxane) of $30 \mathrm{~m} \times 0.25 \mathrm{~mm}$ i.d., $0.25 \mathrm{~mm}$ film thickness, at a constant helium $(99.999 \%)$ flow rate of $1.2 \mathrm{~mL}$ $\min ^{-1}$. An injection volume of $0.5 \mu \mathrm{L}\left(5 \mathrm{mg} \mathrm{mL}^{-1}\right)$ was employed, with a split ratio of 1:10. The oven temperature was programmed from $50^{\circ} \mathrm{C}$ (isothermal for $1.5 \mathrm{~min}$ ), with an increase of $4^{\circ} \mathrm{C} / \mathrm{min}$ to $200^{\circ} \mathrm{C}$, then $10^{\circ} \mathrm{C} / \mathrm{min}$ to $250^{\circ} \mathrm{C}$, ending with a 5 min isothermal, at $25^{\circ} \mathrm{C}$.

The MS and FID data were simultaneously acquired employing a Detector Splitting System; the split flow ratio was 4:1 (MS:FID). A $0.62 \mathrm{~m} \times 0.15$ $\mathrm{mm}$ i.d. restrictor tube (capillary column) was used to connect the splitter to the MS detector; a $0.74 \mathrm{~m} \times$ $0.22 \mathrm{~mm}$ i.d. restrictor tube was used to connect the splitter to the FID detector. The MS data (total ion chromatogram, TIC) were acquired in full scan mode $(\mathrm{m} / \mathrm{z}$ of $40-350)$, at a scan rate of $0.3 \mathrm{scan} / \mathrm{s}$, using the electron ionization (EI), with an electron energy of $70 \mathrm{eV}$. The injector temperature was $250^{\circ} \mathrm{C}$, and the ion-source temperature was $250{ }^{\circ} \mathrm{C}$. The FID temperature was set to $250^{\circ} \mathrm{C}$, and the gas supplies for the FID were hydrogen, air, and helium at flow rates of 30,300 , and $30 \mathrm{~mL} \mathrm{~min}^{-1}$, respectively. Quantification of each compound was estimated by FID peak-area normalization (\%). Compound concentrations were calculated from the GC peak areas and arranged in order of GC elution.

Identification of individual components of the essential oil was carried out by computerized matching of the acquired mass spectra with those stored in the NIST21, NIST107, and WILEY8 mass spectral library of the GC-MS data system. A mixture of hydrocarbons $\left(\mathrm{C}_{9} \mathrm{H}_{20}-\mathrm{C}_{19} \mathrm{H}_{40}\right)$ was injected under these same conditions, and compounds identification was then performed by comparing the spectra obtained in the present study with those of the equipment data bank, and by the retention index, calculated for each component, as previously described (ADAMS, 2007). Retention indices were calculated using the equation proposed by Van Den Dool and Kratz (1963).

\section{Antifungal activity}

Pure cultures of the fungi Fusarium pallidoroseum, Fusarium solani, and Colletotrichum musae were used for the experiment. The material was provided by the Phytopathology Laboratory of the Federal University of Sergipe. The antifungal activity of the essential oils was evaluated against the fungus in a contact trial based on mycelial 
growth inhibition (CHANG et al., 2008). The experimental design was completely randomized with three replications. The essential oils and the major compounds were homogenized in $1 \%$ DMSO (Dimethylsulfoxide) and mixed to PDA culture medium (Potato Dextrose Agar, HIMEDIA). Concentrations starting from $0.1 \mathrm{~mL} / \mathrm{L}$ of essential oil were tested until the fungicidal effect was detected for each chemotype.

Solutions were poured into $9.0 \mathrm{~cm}$ diameter Petri dishes, and each dish was inoculated, in the center, with a $7 \mathrm{~mm}$ diameter disc of the fungus culture, and incubated in a BOD chamber at $22 \pm 3$ ${ }^{\circ} \mathrm{C}$ with a $12 \mathrm{~h}$ photoperiod. The mycelial diameter was measured (mean of two diametrically opposed measurements), using a pachymeter, at 96 hours after incubation. Petri dishes containing only PDA were used as controls. At the end of the evaluations, the mycelial growth inhibition percentage (GIP) of the treatments in relation to the control was calculated using the formula: GIP $=[$ (diameter of the control - diameter of the treatment) /diameter of the control)] x 100.
ALVES, M. F. et al.

For the evaluation of the fungistatic and fungicidal profile of the essential oils and major compounds, mycelial discs were transferred from the treatments that showed no visible growth to new Petri dishes containing only PDA culture medium. The treatment was evaluated for $96 \mathrm{~h}$. Minimal Inhibitory Concentration (MIC) was considered as the lowest concentration with no fungus growth after transfer. Minimal Fungicide Concentration (MFC) was considered as the lowest concentration at which mycelial growth was not observed after transfer.

\section{Statistical analyses}

The means of the mycelial growth inhibition percentage with the respective standard deviations of the mean were obtained with the Graph Pad Prism® software (mean \pm SDM).

\section{RESULTS AND DISCUSSION}

The chemical analysis of the essential oil of three chemotypes of $M$. lundiana was characterized by the presence of terpenes (Table 1).

Table 1. Chemical composition of the essential oils of the three $M$. lundiana chemotypes, according to Alves et al. (2016).

\begin{tabular}{lcccc}
\hline Compounds & IRRl & MLU-005 & MLU-019 & MLU-022 \\
\hline$\square$-pinene & 932 & 5.64 & 0.92 & 5.00 \\
$\square$-pinene & 974 & 11.39 & 0.67 & 9.93 \\
$p$-cymeno & 1020 & 1.54 & 0.94 & 1.86 \\
1,8-cineol & 1026 & $\mathbf{2 5 . 9 3}$ & 14.46 & 11.89 \\
linalool & 1095 & 1.46 & 2.54 & 1.33 \\
neo isopulegol & 1143 & 0.26 & - & - \\
isopulegol & 1145 & - & $\mathbf{4 1 . 0 6}$ & - \\
citronelal & 1148 & - & - & - \\
iso-isopulegol & 1155 & - & 15.26 & - \\
neo iso-isopulegol & 1174 & - & 2.11 & - \\
terpinen-4-ol & 1174 & 4.42 & 2.07 & 1.66 \\
$\square$-terpineol & 1186 & 7.13 & 3.15 & 3.16 \\
citronelol & 1223 & - & 3.17 & - \\
neral & 1235 & 0.23 & - & $\mathbf{2 4 . 2 5}$ \\
geranial & 1249 & 0.34 & - & - \\
methyl nerolate & 1280 & 2.61 & 0.20 & - \\
methyl<8-hydroxy-neo $>$ & 1339 & - & 1.24 & - \\
nerolic acid & $1347 *$ & 24.44 & 20.09 & - \\
$E$-caryophyllene & 1417 & 1.11 & 2.53 & - \\
trans- $\square$-bergamotene & 1436 & - & 0.31 & 0.34 \\
$\square$-selinene & 1489 & 1.53 & - & 2.16 \\
$\square$-selinene & 1498 & 1.13 & - & 0.36 \\
caryophyllene oxide & 1582 & 4.56 & 3.13 & - \\
$Z$ - $\square$-trans-bergamotol & 1713 & - & 0.42 &
\end{tabular}

RRIl: Relative retention index - literature. * Watanabe et al., 2005. 
The chemotype MLU-005 presented 1,8cineole $(25.93 \%)$, nerolic acid $(24.44 \%)$, $\beta$-pinene $(11.39 \%)$, and $\alpha$-terpineol $(7.13 \%)$ as major compounds. The chemotype MLU-019 had isopulegol $(41.06 \%)$, nerolic acid $(20.09 \%)$, neoisopulegol $(15.26 \%)$, and 1,8-cineole $(14.46 \%)$ as major compounds. The chemotype MLU-022 presented citral (neral+geranial) $(55.59 \%=24.25 \%$ $[($ neral $)+31.34 \%$ (geranial) $], 1,8$-cineole $(11.89 \%)$, $\beta$-pinene $(9.93 \%)$, and $\alpha$-pinene $(5.00 \%)$ as major compounds.

All the chemotypes of the essential oil of $M$. lundiana showed antifungal activity against the fungi $F$. pallidoroseum, $F$. solani, and $C$. musae (Table 2). The major compounds showed antifungal activity against $F$. pallidoroseum, $F$. solani, and $C$. musae, especially isopulegol and citral (Table 3).

Table 2. Mycelial growth inhibition percentage (mean \pm standard error of the mean) of the phytopathogenic fungi Fusarium pallidoroseum, Fusarium solani, and Colletotrichum musae in function of the concentrations of the essential oils of the three chemotypes of M. lundiana, after 96 hours of incubation.

\begin{tabular}{|c|c|c|c|}
\hline \multirow{2}{*}{$\begin{array}{l}\text { Essential oil concentration } \\
(\mathrm{mL} / \mathrm{L})\end{array}$} & \multicolumn{3}{|c|}{ Mycelial growth inhibition (\%) of phytopathogenic fungi } \\
\hline & F. pallidoroseum & F. solani & C. musae \\
\hline \multicolumn{4}{|l|}{$\begin{array}{l}\text { Plant MLU-005 (chemotype 1,8- } \\
\text { cineole) }\end{array}$} \\
\hline 0.1 & $39.55 \pm 0.73$ & $18.80 \pm 0.52$ & $61.26 \pm 0.98$ \\
\hline 0.3 & --- & --- & $89.58 \pm 0.79$ \\
\hline 0.4 & --- & --- & $100.0 \pm 0.00 *$ \\
\hline 0.5 & --- & --- & $100.0 \pm 0.00^{* *}$ \\
\hline 1.0 & $87.14 \pm 0.55$ & $43.61 \pm 1.22$ & --- \\
\hline 1.1 & $100.0 \pm 0.00 *$ & --- & --- \\
\hline 1.2 & $100.0 \pm 0.00 * *$ & --- & --- \\
\hline 6.0 & --- & $83.33 \pm 2.06$ & --- \\
\hline 7.0 & --- & $100.0 \pm 0.00^{*}$ & --- \\
\hline 8.0 & --- & $100.0 \pm 0.00^{* *}$ & --- \\
\hline \multicolumn{4}{|l|}{$\begin{array}{c}\text { Plant MLU-019 (chemotype } \\
\text { isopulegol) }\end{array}$} \\
\hline 0.1 & $29.55 \pm 1.11$ & $18.65 \pm 0.73$ & $25.44 \pm 3.25$ \\
\hline 0.5 & $57.25 \pm 0.74$ & $32.67 \pm 2.16$ & --- \\
\hline 0.6 & --- & --- & $83.33 \pm 2.07$ \\
\hline 0.7 & --- & --- & $100.0 \pm 0.00^{*}$ \\
\hline 0.8 & --- & --- & $100.0 \pm 0.00 * *$ \\
\hline 1.0 & $87.26 \pm 0.73$ & $45.25 \pm 2.64$ & --- \\
\hline 1.1 & $100.0 \pm 0.00^{*}$ & --- & --- \\
\hline 1.2 & $100.0 \pm 0.00 * *$ & --- & --- \\
\hline 4.0 & --- & $95.67 \pm 2.63$ & --- \\
\hline 5.0 & --- & $100.0 \pm 0.00^{*}$ & --- \\
\hline 6.0 & --- & $100.0 \pm 0.00 * *$ & --- \\
\hline \multicolumn{4}{|c|}{ Plant MLU-022 (chemotype citral) } \\
\hline 0.1 & $87.14 \pm 0.55$ & $16.55 \pm 4.50$ & $27.98 \pm 10.87$ \\
\hline 0.2 & $100.0 \pm 0.00 *$ & --- & --- \\
\hline 0.3 & $100.0 \pm 0.00 * *$ & --- & --- \\
\hline 0.4 & --- & $83.33 \pm 2.06$ & $83.43 \pm 2.06$ \\
\hline 0.5 & --- & $100.0 \pm 0.00 *$ & $100.0 \pm 0.00 *$ \\
\hline 0.6 & --- & $100.0 \pm 0.00 * *$ & $100.0 \pm 0.00 * *$ \\
\hline
\end{tabular}

* Fungistatic activity; ** Fungicidal activity, 
Table 3. Mycelial growth inhibition percentage (mean \pm standard error of the mean) of the phytopathogenic fungi Fusarium pallidoroseum, Fusarium solani, and Colletotrichum musae in function of concentrations of their major compounds, 1,8-cineole, isopulegol, and citral, after 96 hours of incubation.

Major compound concentration Equivalence in essential Mycelial growth inhibition (\%) of phytopatogenic

\begin{tabular}{|c|c|c|c|c|}
\hline \multirow[b]{2}{*}{$(\mathrm{mL} / \mathrm{L})$} & \multirow{2}{*}{$\begin{array}{c}\text { oil } \\
(\mathrm{mL} / \mathrm{L})\end{array}$} & \multicolumn{3}{|c|}{ fungi } \\
\hline & & F. pallidoroseum & F. solani & C. musae \\
\hline 1,8-cineole & MLU-005 & & & \\
\hline 0.0259 & 0.1 & $63.97 \pm 2.01$ & $27.29 \pm 2.16$ & $27.88 \pm 2.14$ \\
\hline 0.1297 & 0.5 & $66.86 \pm 7.25$ & $29.47 \pm 7.37$ & $30.04 \pm 7.31$ \\
\hline 0.2593 & 1.0 & $69.75 \pm 4.02$ & $40.36 \pm 3.56$ & $35.44 \pm 5.69$ \\
\hline 1.2965 & 5.0 & $71.36 \pm 8.21$ & $43.35 \pm 2.36$ & $40.84 \pm 3.53$ \\
\hline 2.5930 & 10.0 & $74.26 \pm 3.90$ & $52.37 \pm 5.74$ & $43.81 \pm 2.34$ \\
\hline Isopulegol & MLU-019 & & & \\
\hline 0.0411 & 0.1 & $61.70 \pm 0.70$ & $62.15 \pm 4.50$ & $15.13 \pm 2.41$ \\
\hline 0.3695 & 0.9 & --- & --- & $75.49 \pm 1.63$ \\
\hline 0.4106 & 1.0 & $83.52 \pm 3.29$ & $84.20 \pm 1.25$ & $100.0 \pm 0.00^{*}$ \\
\hline 0.4517 & 1.1 & $100.0 \pm 0.00 *$ & $100.0 \pm 0.00 *$ & $100.0 \pm 0.00 * *$ \\
\hline 0.4927 & 1.2 & $100.0 \pm 0.00 * *$ & $100.0 \pm 0.00 * *$ & --- \\
\hline Citral & MLU-022 & & & \\
\hline 0.0556 & 0.1 & $68.80 \pm 0.80$ & $54.52 \pm 3.40$ & $81.09 \pm 2.47$ \\
\hline 0.1112 & 0.2 & --- & --- & $100.0 \pm 0.00 *$ \\
\hline 0.1668 & 0.3 & --- & --- & $100.0 \pm 0.00^{* *}$ \\
\hline 0.2224 & 0.4 & --- & $83.52 \pm 3.29$ & --- \\
\hline 0.2780 & 0.5 & $85.52 \pm 3.20$ & $100.0 \pm 0.00 *$ & --- \\
\hline 0.3335 & 0.6 & $100.0 \pm 0.00 *$ & $100.0 \pm 0.00 * *$ & --- \\
\hline 0.3891 & 0.7 & $100.0 \pm 0.00 * *$ & --- & --- \\
\hline
\end{tabular}

* Fungistatic activity; ** Fungicidal activity,

Fusarium pallidoroseum and Fusarium solani showed similar mycelial growth for the essential oils MLU-005 and MLU-019 until the first 48 hours. The same occurred for the major compounds isopulegol and citral (Figures 1 and 2). The fungus Colletotrichum musae presented total growth control within 48 hours of evaluation, diverging from the other fungi tested (Figure 3).
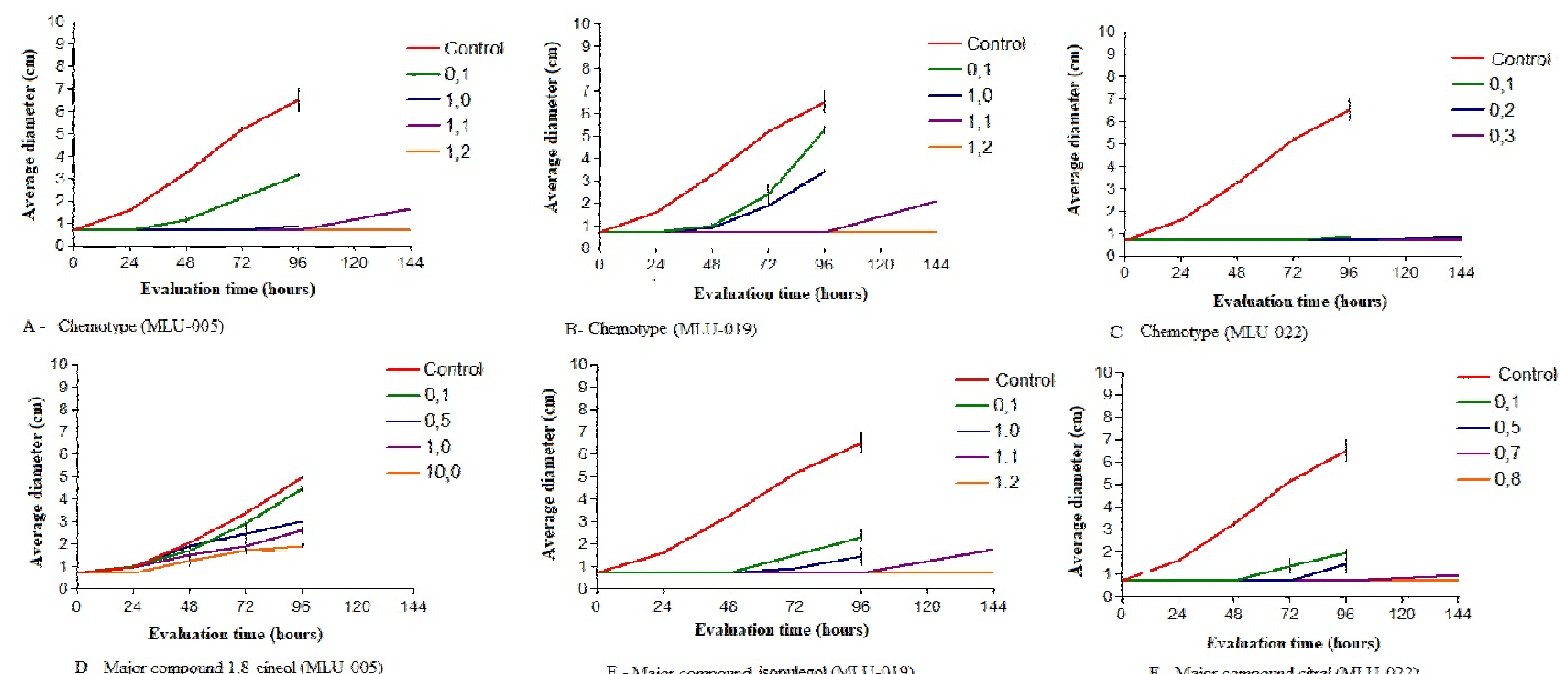

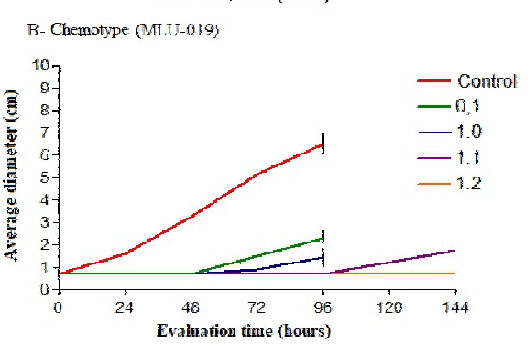

E - Majot compourd isopulegol (NIU-019)

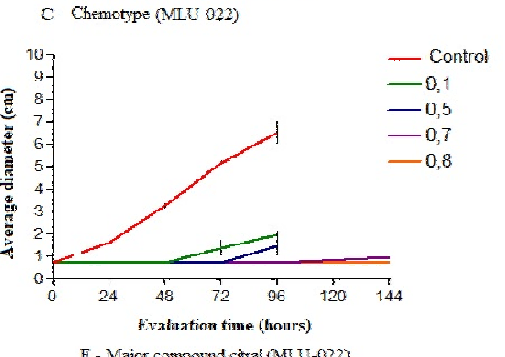

F - Vaicr compond ctral (MLU-022)

Figure 1 Mycelial diameter growth as a function of time, for the essential oils of plants MLU-005, MLU-019, MLU-022, and their major compounds, 1,8-cineole, isopulegol, and citral, during 144 days of evaluation for the fungus Fusarium pallidoroseum. 

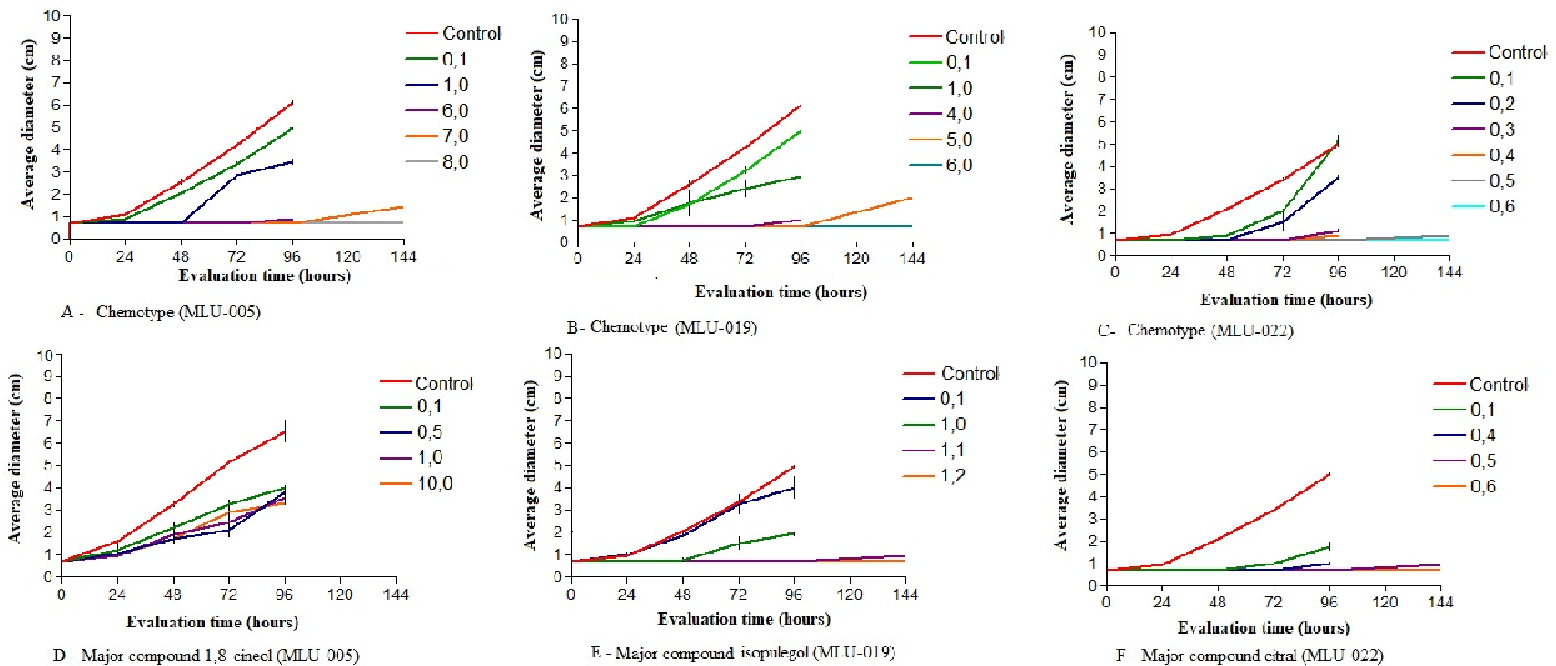

Figure 2. Mycelial diameter growth as a function of time, for the essential oils of plants MLU-005, MLU-019, MLU-022, and their major compounds, 1,8-cineole, isopulegol, and citral, during 144 days of evaluation for the fungus Fusarium solani.
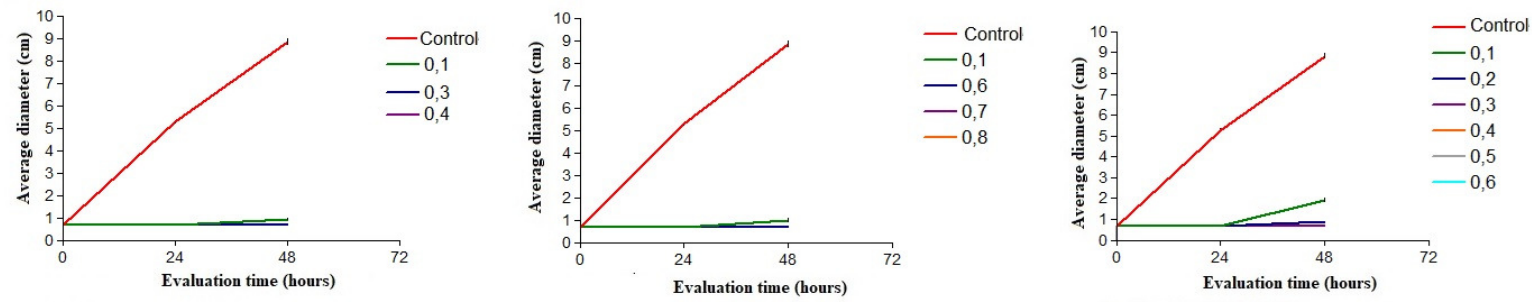

A - Chemotype (MLU-005)

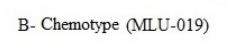

C- Chemotype (MLU-022)
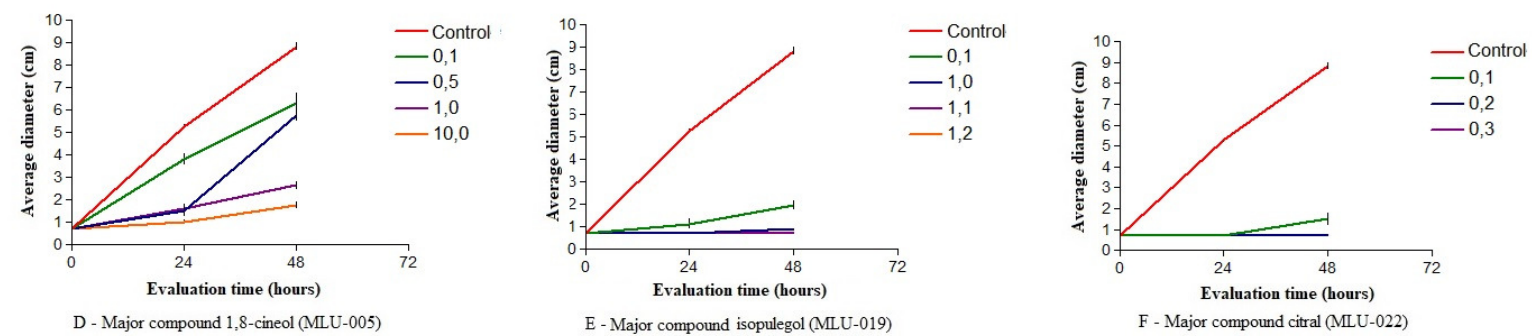

Figure 3. Mycelial diameter growth as a function of time, for the essential oils of plants MLU-005, MLU-019, MLU-022, and their major compounds, 1,8-cineole, isopulegol, and citral, during 144 days of evaluation, for the fungus Colletotrichium musae.

The essential oil of MLU-005 with a high content of 1,8 -cineole $(25.93 \%)$ in its chemical composition provided $100 \%$ mycelial growth inhibition from the concentration of $1.1 \mathrm{~mL} / \mathrm{L}$ (Minimum Inhibitory Concentration - MIC) for the fungus $F$. pallidoroseum, and $7.0 \mathrm{~mL} / \mathrm{L}$ for fungus $F$. solani. The activity of the essential oil MLU-005 was better against C. musae, with MIC of $0.2 \mathrm{~mL} / \mathrm{L}$, providing a superior minimum fungicidal concentration (MFC) of $0.3 \mathrm{~mL} / \mathrm{L}$ (Table 2). The essential oil MLU-005 showed pronounced antifungal activity, whereas 1,8-cineole, one of its major compounds, showed moderate antifungal activity (Tables 2 and 3).
The compound 1,8-cineole was the most abundant in the essential oil MLU-005 tested in this work, and therefore, this compound was expected to be the responsible for the antifungal action of the essential oil (Table 1). However, Table 3 shows that the efficiency of the essential oil is not directly related to the presence of 1,8-cineole. Probably, another compound present in the essential oil or the junction of some compounds is responsible for the mycelial control. Another hypothesis is the synergistic effect. The synergistic interaction of the essential oil compounds and the existence of minor compounds with marked antifungal activity are probable explanations to justify the fact that the 
antifungal activity of the essential oil MLU-005 is superior to that of its major compound (KOROCH et al., 2007; BOSSOLE; JULIANI, 2012)

Similar results were observed for the fungitoxic activity on the mycelial inhibition of the phytopathogens Rhizoctonia solani and Sclerotium rolfsi by testing 1,8-cineole (GONÇALVES et al., 2015). Conversely, this compound was active in the control of $S$. rolfsii in in vivo trials (DERBALAH et al., 2012). However, the authors did not evaluate the effect of the pure compound.

The essential oil MLU-019 and its major compound, isopulegol, showed the same MIC (1.1 $\mathrm{mL} / \mathrm{L})$ when compared with the fungus $F$. pallidoroseum (Tables 2 and 3). This fact confirms that isopulegol alone has a fungicidal activity against the fungus tested; the same is not true for other fungi, especially for $C$. musae, which was more sensitive to the essential oil MLU-019 with MFC of $(0.8 \mathrm{~mL} / \mathrm{L})$ than to its isolate with MFC of $(1.1 \mathrm{~mL} / \mathrm{L})$ (Table 2). Isopulegol is a monoterpene alcohol, present in the essential oil of several species. The inhibitory action of this compound may be associated with its lipophilic character.

The lipophilic character provides greater affinity for organic phases, such as biological membranes, and is more readily dispersible in an organic medium. Thus, it is possible to trigger toxic effects on the structure and function of the cell membranes of the organisms, such as changes in fluidity and permeability, and interaction with internal components of the cell (TROMBETA et al., 2005; COELHO; SANTOS, 2007).

The essential oil MLU-022 presented the same MIC as the citral isolate against $F$. solani $(0.5$ $\mathrm{mL} / \mathrm{L}$ ) (table 2). F. pallidoroseum had lower MIC for the essential oil $(0.2 \mathrm{~mL} / \mathrm{L})$, i.e., the permeability of the cell wall of this fungus is more sensitive to the mixture of the essential oil compounds. For the fungus $C$. musae, MIC was lower for citral isolate (0.2 mL/L) (Table 3). Citral (3.7-dimethyl-2,6octadienal) is a mixture of two isomeric acyclic monoterpene aldehydes: geranial (E-citral) and neral (Z-citral) (COELHO; SANTOS, 2007).

Citral is an antimicrobial agent with antifungal activity on Penicillium digitatum, which causes post-harvest diseases in citrus. The compound modified the mitochondrial morphology and the cell wall function of this phytopathogen, causing a decrease in oxygen level and respiratory rate, which leads to an increase in the permeability of the fungal membrane by the action of this phytochemical on the cell wall (ROZWALKA et al., 2010; FAN et al., 2014).
For the fungi $F$. pallidoroseum and $F$. solani, the most promising essential oil was MLU022. Conversely, MLU-005 was the most promising for the fungus $C$. musae. For the major compounds, citral was the most promising for the three fungi tested. It is suggested that the mechanism of action of the samples tested on the phytopathogenic fungi acted on the principles of synergism and antagonism (TIAN et al., 2012). The essential oil or its pure major compound showed different sensitivity in both fungi tested, being $C$. musae more sensitive than $F$. solani. Studies on the fungicidal mechanism of essential oils indicate that this activity can also be attributed to the phenolic compounds and terpenoids that are present in the structure of the essential oil (KHAN et al., 2011). Moreover, such effect on fungal cell walls may be associated with lipid oxidation of the cell membrane, which is induced by some of the compounds of the essential oil (GILLES et al., 2010).

The lipophilic characteristic of essential oils stands out among the antimicrobial properties. This is because the oils pass through the cell wall and plasma membrane, which may disturb these structures (MONTANARI et al., 2012). This cytotoxic property of essential oils is paramount for agriculture due to the effectiveness of these plant extracts in controlling phytopathogens.

Compounds evaluated in its pure form have presented antimicrobial activity in different studies (BAKKALI et al., 2008; REGNIER et al., 2008; DAN et al., 2010; HUSSAIN et al., 2010; COMBRINCK et al., 2011). The hydrophobicity of essential oils and their compounds should also be taken into account since they can interact with the lipid layer of cell membranes, causing changes in their structures, and rendering them less selective, which may lead to extravasation of ions and other cell constituents (KUMAR et al., 2008).

Results show that the essential oils and their major compounds have antifungal activity, being effective against the fungi $F$. pallidoroseum, $F$. solani, and $C$. musae, except for MLU-005, whose oil was more active than the major compound 1,8cineole. This indicates that the activity of this oil may be related to different combinations of the contents of its major compounds. Moreover, the same essential oil, with the same concentration, presents different fungitoxicity between pathogens.

The essential oils of Myrcia lundiana and its major compounds presented great potential to control the evaluated fungi since small doses significantly reduced the mycelial growth of these pathogens. The essential oils can be used as a 
control option in organic crops or integrated management systems.

\section{ACKNOWLEDGMENTS}

The authors thank CNPq, FAPITEC/SE, CAPES, FINEP, and RENORBIO for their financial support for this work.

RESUMO: O presente trabalho avaliou a atividade antifúngica de óleos essenciais de quimiotipos de Myrcia lundiana dos seus compostos majoritários sobre os fungos Fusarium pallidoroseum, Fusarium solani e Colletotrichum musae. Os óleos essenciais foram obtidos por hidrodestilação e analisados por CGEM/DIC. Para avaliação da atividade antifúngica, foram testados os óleos essenciais e os compostos majoritários na concentração de $0,1 \mathrm{~mL} / \mathrm{L}$ até encontrar o efeito fungicida. Os principais compostos presentes no óleo essencial foram 1,8-cineol, isopulegol e citral. Os quimiotipos (MLU-005 e MLU-019) proporcionaram 100\% de inibição do crescimento micelial para o fungo F. pallidoroseum a partir da concentração de 1,1 mL/L (Concentração Inibitória Mínima - CIM). Para o quimiotipo (MLU-022), a melhor concentração fungicida mínima (CFM) foi de $0,3 \mathrm{~mL} / \mathrm{L}$. Para F. solani, os óleos essenciais dos quimiotipos (MLU-005 e MLU-019) apresentaram CIM nas concentrações de 7,0 e 5,0 mL/L, respectivamente. O óleo essencial do quimiotipo (MLU-022) apresentou CFM de 0,6 mL/L. Observou-se CIM diferenciado para os três quimiotipos estudados para o fungo C. musae, variando entre $0,4 \mathrm{~mL} / \mathrm{L}$, para o quimiotipo (MLU-005); 0,5 mL/L, para o quimiotipo (MLU-022); e 0,7 mL/L, para o quimiotipo (MLU-019). O quimiotipo MLU-005 apresentou o melhor CFM, 0,5 mL/L. Os compostos majoritários testados separadamente apresentaram melhores valores de CIM frente aos seus quimiotipos, exceto o composto 1,8-cineol, que apresentou menor inibição do crescimento micelial para os três fungos testados, sugerindo que o perfil químico ou a presença de algum outro composto no óleo essencial pode estar atuando na inibição do crescimento dos três fungos estudados. O composto isopulegol proporcionou menor CFM para o fungo C. musae $(0,4517 \mathrm{~mL} / \mathrm{L})$ em relação aos fungos F. pallidoroseum e $F$. solani, para os quais apresentou CFM de $0,4927 \mathrm{~mL} / \mathrm{L}$. O composto citral proporcionou um menor CFM sobre o fungo C. musae $(0,1668 \mathrm{~mL} / \mathrm{L})$, em relação aos demais fungos testados. Os óleos essenciais de quimiotipos de $M$. lundiana e seus compostos majoritários apresentaram potencial para o controle dos fitopatógenos estudados, podendo ser considerados como uma alternativa para a agricultura, uma vez que em concentrações mais baixas apresentaram efeito inibitório e fungicida frente a estes organismos.

PALAVRAS CHAVE: Myrtaceae. Óleo volátil. Monoterpenos. Fusarium pallidoroseum. Fusarium solani e Colletotrichum musae.

\section{REFERENCES}

ALVES, M. F.; NIZIO, D. A. C.; SAMPAIO, T. S.; NASCIMENTO JUNIOR, A. F; BRITO, F. A.; MELO, J. O.; ARRIGONI-BLANK, M. F.; GAGLIARDI, P. R.; MACHADO, S. M. F.; BLANK, A. F. Myrcia lundiana Kiaersk native populations have different essential oil composition and antifungal activity against Lasiodiplodia theobromae. Industrial Crops and Products, Holanda, v. 85, p. 266-273, july. 2016. http// doi.org/10.1016/j.indcrop.2016.03.039

ADAMS, R. P. Identification of essential oil components by gas chromatography/mass spectroscopy. 4th ed., Allured: Carol Stream, 2007. 804p.

BAKKALI, F.; AVERBECK, D.; IDAOMAR, M. Biological effects of essential oils - A review. Food and Chemical Toxicology, USA, v. 46, n. 2, p. 446-475, fev. 2008.

http//doi.org/10.1016/j.fct.2007.09.106

BASSOLÉ, I. H. N.; JULIANI, H. R. Essential oils in combination and their antimicrobial properties. Molecules, Suiça, v. 17, n. 4, p. 3989-4006, abr. 2012.

http//doi.org/10.3390/molecules17043989

CARRER, H.; BARBOSA, A. L.; RAMIRO, D. A. Biotecnologia na agricultura. Estudos Avançados, v. 24, p. 149$164,2010$. 
CHANG, H. T.; CHENG, Y. H.; WU, C. L.; CHANG, S. T.; CHANG, T. T.; SU, Y. C. Antifungal activity of essential oil and its constituents from Calocedrus macrolepis var, formosana florin leaf against plant pathogenic fungi. Bioresource Technology, Mohali, v. 99, n. 14, p. 6266-6270, fev. 2008.

http//doi.org/10.1016/j.biortech.2007.12.005

COELHO, A. C. V.; SANTOS, P. S. Argilas especiais: argilas quimicamente modificadas - uma revisão. Química Nova, São Paulo, v. 30, n. 5, p. 1282-1294, july. 2007.

http:// doi.org/10.1590/S0100-40422007000500042

COMBRINCK, S.; REGNIER, T.; KAMATOU, G. P. P. In vitro activity of eighteen essential oils and some major components against common postharvest fungal pathogens of fruit. Industrial Crops and Products, Holanda, v.33, p. 344-349, july. 2011.

https://doi.org/10.1016/j.indcrop.2010.11.011

CRUZ, T. P.; ALVES, F. R.; MENDONÇA, R. F.; COSTA, A. V.; JESUS JUNIOR, W. C.; PINHEIRO, P. F.; MARINS, A. K. Atividade fungicida do óleo essencial de Cymbopogon winterianus JOWIT (citronela) contra Fusarium solani. Bioscience Journal, Uberlândia, v. 31, n. 1, p. 1-8, july. 2015.

http://doi.org/10.14393/10.14393/BJ-v31n1a2015-22346

DAN, Y.; LIU, H. Y.; GAO, W. W.; CHEN, S. L. Activities of essential oils from Asarum heterotropoides var. mandshuricum against five phytopathogens. Crop Protection, v. 29, n. 3, p. 295-299, marc. 2010. https://doi.org/10.1016/j.cropro.2009.12.007

DERBALAH, A. S.; DEWIR, Y. H.; EL-SAYED, A. EN. B. Antifungal activity of some plant extracts against sugar beet damping-off caused by Sclerotium rolfsii. Annals of Microbiology, Milão, v. 62, n. 3, p. 1021-1029, sep. 2012. https://doi.org/10.1007/s13213-011-0342-2.

EHLERT, P. A. D.; BLANK, A. F.; ARRIGONI-BLANK, M. F.; PAULA, J. W. A.; CAMPOS, D. A.; ALVIANO, C. S. Tempo de hidrodestilação na extração de óleo essencial de sete espécies de plantas medicinais. Revista Brasileira de Plantas Medicinais, Botucatu, v. 8, n. 2, p. 79-80, 2006. http://ri.ufs.br/handle/123456789/1548

FAN, F.; TAO, N.; JIA, L.; HE, X. Use of citral incorporated in postharvest wax of citrus fruit as a botanical fungicide against Penicillium digitatum. Postharvest Biology and Technology, v. 90, p. 52-55, abr. 2014. https://doi.org/10.1016/j.postharvbio.2013.12.005

GILLES, M.; ZHAO, J.; AN, M.; AGBOOLA, S. Chemical composition and antimicrobial properties of essential oils of three Australian Eucalyptus species. Food Chemistry, Países Baixos, v. 119, n. 2, p. 731-737, marc. 2010. https://doi.org/10.1016/j.foodchem.2009.07.021

GONÇALVES, A. H.; PEREIRA, A. S.; SANTOS, G. R. S.; GUIMARÃES, L. G. L. Atividade fungitóxica in vitro dos óleos essenciais de Lippia sidoides Cham., Cymbopogon citratus(D.C.) Stapf. e de seus constituintes majoritários no controle de Rhizoctonia solani e Sclerotium rolfsii. Revista Brasileira de Plantas Medicinais, Botucatu, v. 17, n. 4, p. 1007-1015, may. 2015.

http://doi.org/10.1590/1983-084x/14_166

HUSSAIN, A.; ANWAR, F.; NIGAM, P.S.; ASHARF, M.; GILANI, A. H. Seasonal variation in content, chemical composition and antimicrobial and cytotoxic activities of essential oils from four Mentha species. Journal of the Science of Food and Agriculture, New York, v. 90, n. 11, p. 1827-1836, aug. 2010. http://doi.org/10.1002/jsfa.4021

KHAN, M. S. A.; AHMAD, I. Antifungal activity of essential oils and their synergy with fluconazole against drugresistant strains of Aspergillus fumigatus and Trichophyton rubrum. Applied Microbiology and Biotechnology, v. 90, n. 3, p. 1083-1094, may. 2011. http://doi.org/10.1007/s00253-011-3152-3 
KOROCH, A. R.; JULIANI, H. R., ZYGADLO, J. A. Bioactivity of essential oils and their components. In Flavours and fragrances, Springer Berlin Heidelberg, p. 87-115, jan. 2007.

http://doi.org/10.1007/978-3-540-49339-6_5

KUMAR, A.; SHUKLA, R.; SINGH, P.; PRASAD, C. S.; DUBEY, N. K. Assessment of Thymus vulgaris L. essential oil as a safe botanical preservative against postharvest fungal infestation of food commodities. Innovative Food Science \& Emerging Technologies, v. 9, n.4, p. 575-580, oct. 2008. https://doi.org/10.1016/j.ifset.2007.12.005

MONTANARI, R. M.; BARBOSA, L. C. A.; DEMUNER, A. J.; SILVA, C. J.; ANDRADE, N. J.; ISMAIL, F. M. D.; BARBOSA, M. C. A. Exposure to Anacardiaceae volatile oils and their constituents induces lipid peroxidation within food-borne bacteria cells. Molecules, Suiça, v. 17, n. 8, p. 9728-9740, aug. 2012.

https://doi.org/10.3390/molecules17089728.

PESSOA, W. R. L. S.; OLIVEIRA, S. M. A.; DANTAS, S. A. F.; TAVARES, S. C. C.; DE H., SANTOS, A. M. G. Efeito da temperatura e período de molhamento sobre o desenvolvimento de lesões de Colletotrichum musae em banana. Summa Phytopathologica, Botucatu, v. 33, n. 2, p.147-151, nov. 2007.

http://org/10.1590/S0100-54052007000200008

REGNIER, T.; PLOOY, W.; COMBRINCK, S.; Botha, B. Fungitoxicity of Lippia scaberrima essential oil and selected terpenoid components on two mango postharvest spoilage pathogens. Postharvest Biology and Technology, p. 48 , n. 2, p. 254-258, may. 2008.

https://doi.org/10.1016/j.postharvbio.2007.10.011

ROZWALKA, L. C.; ALVES, E.; AMARAL, D. C. Ultrastructural study of conidia of Colletotrichum gloeosporioides and Colletotrichum musae treated with essential oils. Interciencia, Caracas, v. 35, n. 12, p. 912-915, dec. 2010.

SAMEZA, M. L.; MABOU, L. C. N.; TCHAMENI, S. N.; BEDINE, M. A. B.; TCHOUMBOUGNANG, F.; DONGMO, P. M. J.; FEKAM, F. B. J. Evaluation of Clove Essential Oil as a Mycobiocide Against Rhizopus stolonifer and Fusarium solani, Tuber Rot Causing Fungi in Yam (Dioscorea rotundata Poir.). Journal of Phytopathology, p. 164, n. 7, p. 433-440, jan. 2016.

https://doi.org/10.1111/jph.12468

TERAO, D.; OLIVEIRA, S. M. A.; VIANA, F. M. P.; SÁ, C. R. L.; MOURA, R. D.; GONDIM, D. M. F. Manejo da podridão de melão pelo controle do amadurecimento através do 1-mcp, sob duas condições de armazenamento.

Summa Phytopathologia, Botucatu, v. 26, n. 2, p. 110-115, 2009.

http://dx.doi.org/10.1590/S0100-54052009000200005

TIAN, J.; BAN, X.; ZENG, H.; HE, J.; CHEN, Y.; WANG, Y. The mechanism of antifungal action of essential oil from dill (Anethum graveolens L.) on Aspergillus flavus. Plos One, EUA, v. 7, n. 1, e30147, 2012.

https://doi.org/10.1371/journal.pone.0030147

TROMBETA, D.; CASTELLI, F.; SARPIETRO, M. G.; VENUTI, V.; CRISTANI, M.; DANIELEe, C. S. I. J.; MAZZANTI, G.; BISIGNANANO, G. Mechanisms of Antibacterial Action of Three Monoterpenes. Antimicrobial Agents and Chemotherapy, Washington, p. 49, n. 6, p. 2474-2478, jun. 2005.

https://doi.org/10.1128/AAC.49.6.2474-2478.2005

VAN DEN DOOL, H.; KRATZ, P. D. A generalization of the retention index system including linear temperature programmed gas-liquid partition chromatography. Journal of Chromatography, USA, v. 11, p. 463-471, aug. 1963. https://doi.org/10.1016/S0021-9673(01)80947-X

WHITT, J.; SHIPLEY, S. M.; NEWMAN, D. J.; ZUCK, K. M. Tetramic acid analogues produced by coculture of Saccharopolyspora erythraea with Fusarium pallidoroseum. J. Nat. Prod., v. 77, n. 1, p. 173-177, jan. 2014. https://doi.org/10.1021/np400761g 